\title{
Neuronally derived extracellular vesicles: an emerging tool for understanding Alzheimer's disease
}

\author{
Luke S. Watson ${ }^{1,2}$, Eric D. Hamlett ${ }^{3}$, Tyler D. Stone ${ }^{1,4}$ and Catrina Sims-Robinson ${ }^{1,2^{*}}$ (D)
}

\begin{abstract}
In order for Alzheimer's disease (AD) to manifest, cells must communicate "pathogenic material" such as proteins, signaling molecules, or genetic material to ensue disease propagation. Small extracellular vesicles are produced via the endocytic pathways and released by nearly all cell types, including neurons. Due to their intrinsic interrelationship with endocytic processes and autophagy, there has been increased interest in studying the role of these neuronally-derived extracellular vesicles (NDEVs) in the propagation of AD. Pathologic cargo associated with $A D$ have been found in a number of studies, and NDEVs have been shown to induce pathogenesis in vivo and in vitro. Exogenous NDEVs are also shown to reduce plaque burden in AD models. Thus, the NDEV has the potential to become a useful biomarker, a pathologic potentiator, and a therapeutic opportunity. While the field of NDEV research in $A D$ is still in its infancy, we review the current literature supporting these three claims.
\end{abstract}

Keywords: Autophagy, Beta-amyloid, Cognitive impairment, Dementia, Exosome, Mammalian target of rapamycin, Neurodegeneration, Tau

\section{Background}

For decades, therapies for Alzheimer's disease (AD) have targeted beta-amyloid $(A \beta)$ and phosphorylated tau proteopathies. Unfortunately, research has not yielded any viable therapeutics over the past 20 years. This lack of progress may be due to the complexity and heterogeneous nature of clinical AD. Approximately $80 \%$ of $\mathrm{AD}$ subjects present with multiple pathologies post-mortem such as amyloid, tau, vascular disease, Lewy Bodies, and alpha-synuclein [1-3]. Interestingly, nearly $70 \%$ of cognitively normal individuals also present with the same post-mortem pathology. Hence, there is a need for a paradigm shift in the field away from a focus on specific proteins and towards understanding the cellular abnormalities and processes that contribute to abnormal protein accumulation. Autophagy is the cell's strategy to regulate metabolism by recycling intracellular materials

\footnotetext{
* Correspondence: robinsoc@musc.edu

${ }^{1}$ Department of Neurology, Medical University of South Carolina, 96 Jonathan Lucas Street, 301 Clinical Sciences Building, MSC 606, Charleston, SC 29425, USA

${ }^{2}$ Molecular and Cellular Biology and Pathobiology Program, Medica University of South Carolina, Charleston, Charleston, SC 29425, USA Full list of author information is available at the end of the article
}

such as proteins into their basic parts, so as to be re-utilized for other purposes [4]. This degenerative process can occur two ways, either dysfunctional proteins are captured by the lysosome for direct degradation [5], or dysregulated cytoplasmic materials are internalized into a double membrane structure referred to from here on out as "autophagosomes" before incorporating into the lysosome for degradation [6]. In addition to breaking down discrete cytosolic materials, autophagosomes can incorporate entire organelles for degradation; in fact, this often occurs to mitochondria in metabolically stressed cells [7].

The field has recently begun focusing on lysosomal and mitochondrial dysregulation as an early pathogenic "trigger" for $\mathrm{AD}$ [8]. In order for disease to manifest, cells must communicate their pathogenic substances, which includes proteins, signaling molecules, or genetic material to ensue disease propagation. This may be accomplished by packaging the pathogenic substances into compartments, known as extracellular vesicles (EVs), which travel between cells. Small EVs produced via endocytic pathways are released by nearly all cell types, including neurons [9]. EVs contain proteins, lipids, and genetic material such as DNA, 
mRNA, and microRNA. They are released into extracellular space to facilitate intercellular communication, export waste, and interact with the microglia $[10,11]$. EVs are implicated in the spread of pathological proteins involved in neurodegenerative diseases including AD [12]. Over the last several years, EVs have emerged as a potential biomarker, potentiator, and therapeutic option, and this review seeks to synthesize the evidence collected to date. The goal of this article is to show that through the abnormal induction of autophagy seen in $\mathrm{AD}$, the EV can serve in all three of these roles.

\section{Extracellular vesicles are an alternate end-product of endocytosis and interact with autophagic processes Genesis of the extracellular vesicle}

Small EVs are often cited having a diameter less than 150 $\mathrm{nm}[13,14]$ and are responsible for the export of waste, interaction with the immune system, and communication between cells $[10,11,13]$. They are a byproduct of the endocytic pathway, and their release is contingent on the association of a multivesicular body (MVB) with the plasma membrane, which causes them to be released into the extracellular space [15]. The process of endocytosis is responsible for the internalization of extracellular proteins and biological material into the cell via invagination of the plasma membrane, through clathrin or non-clathrin mediated processes [16]. Endocytosed cargo is transported to a collection of other internalized bilayer micelles located near the periphery, and along with products of the trans-Golgi pathway create the MVB, mediated early on in the process by the key protein Rab5 [13]. Multiple tagging proteins such as the endosomal sorting complexes required for transport (ESCRT) complex are essential in determining the fate of MVBs and include the protein Vps4, which is involved with terminating the budding into the MVB [17]. Often, the MVBs are brought to the trans-Golgi network for refinement and modification of their cargo $[18,19]$ or for association with the autophagic processes for degradation and reutilization [20]. A key regulator in the process of autophagy is the interplay between insulin and the mammalian target of Rapamycin (mTOR) signaling [21-24].

Signaling from the mTOR pathway activates downstream effectors that stimulate cell growth, survival, cytoskeletal reorganization, and metabolic processes [22]. When these signals are turned off, such as in states of insulin resistance, the mTOR pathway ceases to initiate these proliferative cellular responses and, consequently, the cell switches on autophagy [25]. Therefore, it is no surprise that mTOR is a key modulator of aging and age-related disease and its initiation of autophagy has been linked to the accumulation of protein aggregates and dysfunctional organelles associated with cellular dysfunction. In fact, mTOR activity has been linked to disease progression in mouse models of $\mathrm{AD}[26,27]$ and frontotemporal lobar dementia [28]. Finally, mTOR activity significantly impacts spatial learning and memory in aged mice $[29,30]$. There is evidence suggesting that dysregulated insulin signaling [31], which is upstream of mTOR signaling, may contribute to $\mathrm{AD}$ pathogenesis. A recent study observed that upregulation of mTOR activity in vitro increased the levels of cytosolic tau, facilitated intracellular tau deposition and mediated tau localization to EVs [32]. Given that tau and A $\beta$ are inducers of excitotoxicity in neurons [33], this provides evidence for the involvement of EVs as a potential feed forward loop, poising the system for pathogenesis.

\section{$A D$ pathogenic proteins interact with endosomes and are found in EVs}

$\mathrm{A} \beta$ and hyperphosphorylated tau also interact with the endocytic pathway and may contribute to EV biogenesis in AD. Secretion of EVs is generally thought to increase in response to stress or pathological conditions [14]. For example, the total number of circulating EVs were significantly increased in mice after chronic alcohol feeding and in humans suffering with alcoholism. [34]. In addition, increased EV release has been demonstrated in hypoxia [35], cisplatin- or irradiation-induced DNA damage [36, 37] and through oxidative stress [38]. Studies have shown that depolarization of cells, either by $\mathrm{Ca} 2+$ or $\mathrm{K}+$ influx has been shown to increase MVB association with the plasma membrane, thereby increasing EV secretion $[39,40]$. A recent study reports no difference in the total number and size distribution of EVs from the neuron isolated from blood between age-matched controls and mild cognitively impaired (MCI) subjects [41]. Inhibiting the formation, secretion, or uptake of EVs reduces the spread of oligomers and neurotoxicity [42]. Although additional studies are warranted, this suggests that the pathogenic cargo within the EVs are more important than the total number of $\mathrm{EVs}$ in $\mathrm{AD}$. Below is a summary of proteins currently known to be related to neuronally derived EVs (NDEVs) in $\mathrm{AD}$ patients.

\section{$A \beta$}

The amyloidosis hypothesis of $\mathrm{AD}$ suggests that $\mathrm{A} \beta$ plaque accumulation leads to impaired neuronal signaling and eventually cell death [43]. Mutations in genes associated with this toxicity include aberrant activity of BACE 1, which then leads to accumulation of $A \beta 42$ toxic plaques [44]. A $\beta$ is a c-terminal cleavage product of the amyloid precursor protein (APP), which is a transmembrane protein found in endosomal membranes [45] and, to a lesser extent, the mitochondrial membrane [46]. Notably, APP has been shown to impede the functioning of the mitochondria in association with p53 and an increase of 
cytosolic reactive oxygen species, indicating that high levels of APP can lead to toxicity of the neuron [47]. There are multiple reports of these proteins and their substrates within EVs of in vitro AD models and EVs derived from neurons of $\mathrm{AD}$ patients. EVs isolated from neuronal cell lines show that inducing $\mathrm{AD}$ mutations can increase soluble APP (sAPP) protein $\beta$, sAPP $\alpha$ [13] and soluble A $\beta 1-$ 42 [48]. Cells expressing AD-related genotypes have also shown an upregulation in C-end terminal fragments (a byproduct of APP after beta-secretase processing) [49], beta-secretase in released EVs, and co-localization of beta-secretase enzyme 1 with early EV markers [13]. Experiments involving depleting the media show that $A \beta$ is associated with the EVs during the excretion process [50].

NDEVs isolated from AD patients also have a significant increase in soluble A $\beta 1-42$ [41, 51-55]. Notably, NDEVs isolated from AD patients have increased levels of C-terminal fragments of the APP as well [45, 49]; compared to control subjects, NDEVs isolated from AD patients show enrichment of undigested lysosomal APP C-terminal fragments [45]. A $\beta$ plaques also display interactive prion protein receptors, which is reported to increase the pathogenicity of the disease [56]. Recently muskelin, a protein involved with the reorganization of the cytoskeleton, has been implicated in the decision for either lysosomal degradation or EV secretion of the prion receptor protein, which may have implications in amyloidosis [57]. Finally, in a recent study between healthy controls and age-matched clinical AD cohorts, EV-bound $A \beta$ strongly correlated with PET imaging of brain amyloid plaque load while unbound freely circulating $A \beta$ did not [42]. Collectively, EV transfer of $A \beta$ seems to be centrally involved in $A D$ and can serve as a useful antemortem biomarker of disease progression.

\section{Hyperphosphorylated tau}

The gradual deposition of hyperphosphorylated tau protein within select neuronal types is central to the tauopathy component of $\mathrm{AD}$ [58]. For neuronal synapse formation to occur, microtubule elongation needs to occur. This is a process reliant on the incorporation of the neuronal microtubule-associated protein tau [59]. Tau also plays a role in axonal transport and neurite outgrowth, and all these functions are modulated by site-specific phosphorylation. Abnormal hyper-phosphorylation of tau leads to destabilization of microtubule networks, disruption of axonal transport processes and eventually to the accumulation of intra-neuronal neurofibrillary tangles, which are the other classical, pathological hallmarks of advanced stage AD [60, 61]. Despite the heterogeneity of onset in the disease, the progressive accumulation of neurofibrillary tangles are found to be highly correlative to the symptomatic onset of dementia in patients suffering with AD [62]. As tau becomes hyper-phosphorylated in neurons, cellular clearance machinery takes it up for degradation [63].

NDEVs from AD patients show an increase in tau phosphorylation at threonine 181 (p-T181-tau) and serine 396 (p-S396-tau) by 3-20-fold compared to NDEVs obtained from age-matched controls [41, 51, 52, 55]. Moreover, p-T181-tau levels are significantly higher in NDEVs isolated from later stage $\mathrm{AD}$ patients than from when they were still diagnosed with MCI [41], implicating either a disruption in the clearance capabilities or an enhancement in pathogenicity of EVs in later disease states. p-T181- and p-S396-tau were significantly lower in NDEVs of patients 1-10 years prior to their AD diagnosis [52].

\section{Dysfunctional insulin signaling}

Central nervous system dysregulated insulin and peripheral hyperinsulinemia has been shown to be another highly associated phenomenon with $\mathrm{AD}[31,64-66]$. Insulin dysregulation can be characterized by low ratios of tyrosine phosphorylated insulin receptor substrate 1 (IRS1) to serine phosphorylated IRS1 [67, 68] and has been correlated with greater brain atrophy in humans with $\mathrm{AD}$ [55]. Chronic high-fat diet fed mice exhibit this post-translational modification shift in hippocampal slices [69]. Downstream, insulin signaling induces transduction pathways involving protein kinase B (Akt), and this dysregulated phosphorylation of IRS1 induces mTOR's initiation of autophagy via de-phosphorylated Akt (Fig. 1). NDEVs isolated from AD patients have shown an increase in serine phosphorylation of IRS1 [70]. The group report that the differences in the IRS1 profiles were identifiable up to 10 years prior to clinical onset of AD. This suggests that proteins within NDEVs involved in insulin dysregulation may be a useful biomarker.

\section{Synaptic proteins}

The consequence of $\mathrm{AD}$ is a loss of neuronal health and function. NDEV cargo of AD patients display reduced levels of synapse proteins, including synaptotagmins, synaptophysin, synaptobrevin, synaptopodin, Rab3A, growth associated protein (GAP) 43, and neurogranin [71]. Also, low-density lipoprotein receptor-related protein (LRP) 6, heat shock factor protein 1, heat shock protein (HSP), and RE1 silencing transcription factor (REST 1) are also lower in NDEVs of AD patients [41, 51, 72]. The $\alpha$-amino-3-hydroxy-5-methyl-4-isoxazolepropionic acid receptor (AMPAR) is also shown to be downregulated in NDEVs of AD patients. Additionally, neurexin $2 \alpha$, GluA4-containing glutamate receptor, and neuroligin 1, all proteins essential for long-term potentiation processes, are all significantly lower in NDEVs of patients $6-11$ years prior to $\mathrm{AD}$ diagnosis and, along with neuronal pentraxin 2, are all downregulated in NDEVs of AD patients [73]. These proteins are all involved with normal homeostatic 


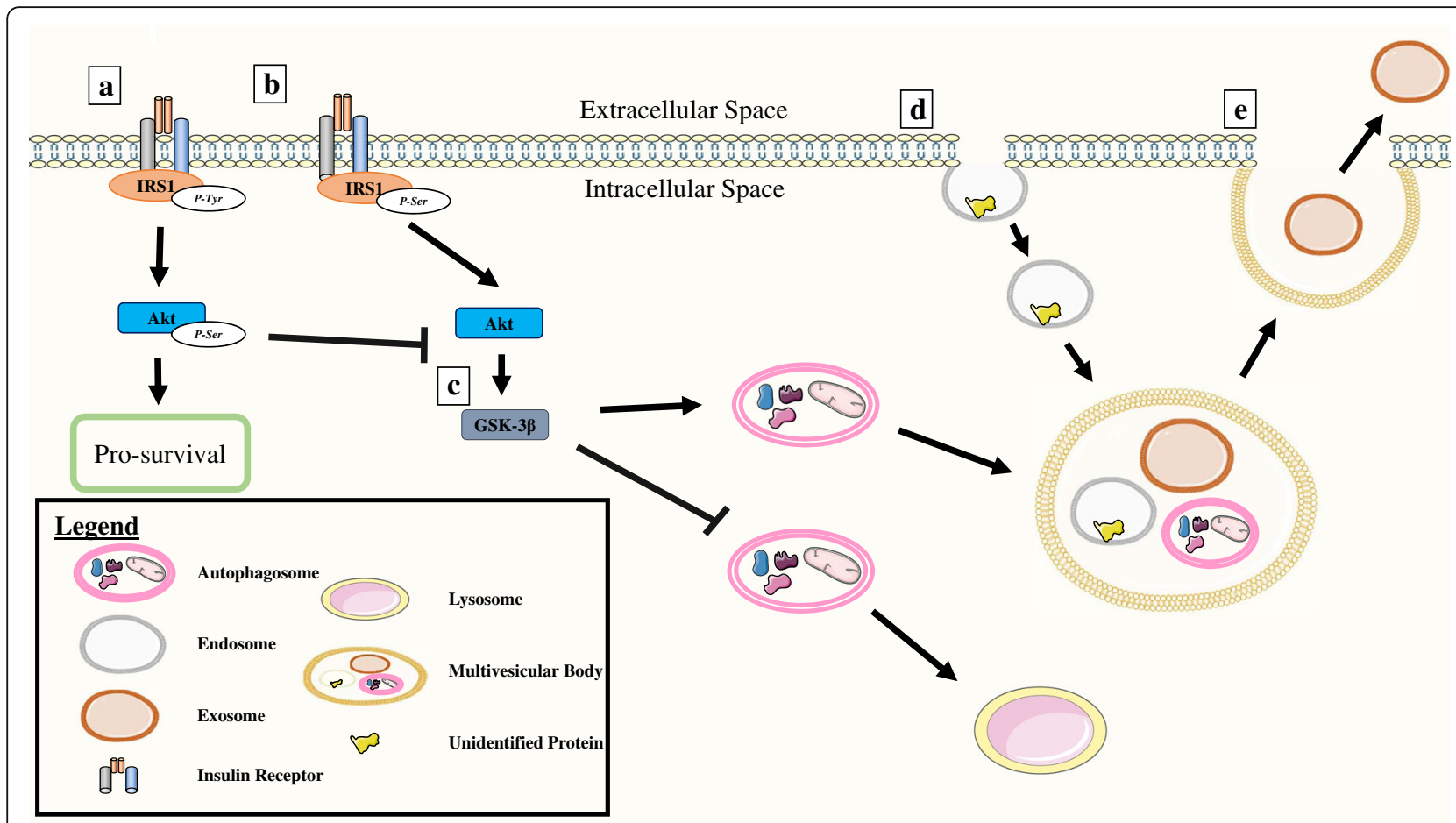

Fig. 1 Outline for exosome secretion. a Normal stimulation of the insulin receptor leads to tyrosine phosphorylation of the insulin receptor susbtrate-1 (IRS1), initiating phosphorylated protein kinase b (Akt) inhibition of glycogen synthase kinase (GSK)-3 $\beta$ and activation of pro-survival signals. $\mathbf{b}$ Lack of stimulation or overstimulation at the insulin receptor leads to serine phosphorylation of the IRS1, which leads to

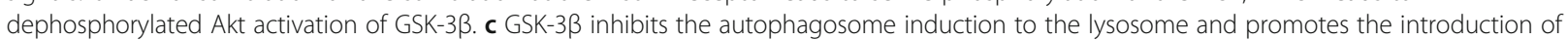
the autophagosome to the multivesicular body (MVB). $\mathbf{d}$ Endocytosis allows for introduction of internalized proteins into the MVB. e MVB associates with the plasma membrane, allowing for exosome release from the cell

processes of neurons. Further research into these cargo levels could be beneficial to clinicians who are currently searching for earlier biomarkers of disease; biomolecules shown to have changed concentrations in $\mathrm{AD}$ patient NDEVs are listed in Additional file 1: Table S1.

\section{EVs in biomedical research EVs in toxicity studies}

For $\mathrm{AD}$ propagation to occur via EVs, EVs must have the ability to transfer pathology between individual cells. Studies involving in vitro methods have supported the notion of pathogenic propagation by EVs. Eitan et al. used multiple genetically manipulated cell lines to characterize the cargo released in EVs and showed an increase in $\mathrm{A} \beta 42$ / A $\beta 40$ ratio compared to controls [50]. They went on to show that co-incubation of rat cortical neurons with EVs isolated from $\mathrm{AD}$ transgenic cell lines had a similarly detrimental effect as co-incubation with medium concentrated in $A \beta$ alone [48]. Co-incubation of neuronal cells derived from transgenic $\mathrm{AD}$ mouse models and EVs derived from adipose differentiated stem cells reduces pathology and apoptosis markers [74]. EVs isolated from post-mortem AD brains that contained increased levels of $A \beta$ oligomers have been shown to act as toxic species to cultured neurons
[75]. Blocking the formation, secretion or uptake of EVs was found to reduce both the spread of $A \beta$ and the related cellular toxicity in these conditions [42]. These in vitro experiments provide sound mechanistic evidence of the pathogenicity potential of EVs but lack the in vivo support.

Probably the most compelling evidence for pathogenic spread is through a recent study by Winston and colleagues [41]. NDEVs isolated from patients diagnosed with either MCI or a more advanced stage of $\mathrm{AD}$ were microinjected into the hippocampus of wild type C57/BL6 mice. Phosphorylated tau reactivity increased in the mice one-month post-injection with $\mathrm{MCI}$ and $\mathrm{AD}$ derived EVs. Overall, this data demonstrates that NDEVs isolated from $\mathrm{MCI}$ and $\mathrm{AD}$ patients are capable of propagating tau pathology in normal mice. Additional studies have provided further evidence of this phenomenon with tau and other proteopathies, adding validity to the approach [76, 77]. Recently, when EV formation was blocked by inhibition of neutral sphingomyelinase-2 (nSMase2), AD pathology was decreased and improvements in memory were observed in an $\mathrm{AD}$ mouse model [78]. Altogether, the results of these provide rationale to pursue a means of inhibiting EV 
secretion as a potential therapy for individuals at risk for developing AD. Overall, these studies suggest a need for further investigation of the in vivo pathogenic potential of EVs.

The EV has the capability of transmitting disease through prion receptor protein (PrP) activity [79]. PrP is a cell surfaced anchored protein with unknown physiological functioning, but is highly associated with $\mathrm{AD}$ pathology [80]. Its pathological, misfolded form is protease-k-resistant and is implicated in encephalopathies [81]. Research in animal models of AD have shown that the prion receptor is necessary for the cognitive impairment associated with $A \beta$ [82], however in other studies, PrP has been shown to mediate toxicity both in vitro and in vivo [83]. It is clear that this warrants further exploration, as the prion receptor likely to plays multiple roles associated with $\mathrm{AD}$ pathological proteins [84]. In $\mathrm{AD}$, there is growing evidence for the prion receptorcontaining EV being capable of spreading pathology [79, 85]. Aberrant autophagy may play a role in this spread [8]. While there is clearly a need for more research in order to understand this relationship, these findings suggest a potential mechanism connecting $\mathrm{AD}$ pathogenesis, the EV, and autophagy.

\section{EVs as novel $A D$ therapeutics}

While EVs may play a role in the spreading of the disease, some studies have demonstrated a positive effect of introducing non-pathogenic EVs to alter the course of pathology and disease. This therapeutic effect was observed when EVs from young mice were found to significantly decrease aging-associated signaling molecules such as mTOR in aged mice [86]. Furthermore, EVs introduced into the brain of an $\mathrm{AD}$ transgenic mouse can benefit the clearance of toxic oligomers in vivo [87, 88], indicating the role of EVs in the interaction with amyloid plaques, which are known to have prion receptor proteins [13, 89]. As described above, Yuyama and colleagues showed that the introduction of naïve EVs into the brain of $\mathrm{AD}$ transgenic mouse models helped in the clearance of toxic fibrils $[88,90]$. Others have suggested that EVs derived from mesenchymal stromal cells may have a therapeutic benefit in the promotion of neurovascular plasticity in other neurodegenerative diseases such as stroke in vivo [91]. Introducing exogenous EVs into the central nervous system is a potentially novel strategy for creating therapies for AD due to their ability to cross the blood-brain barrier efficiently [92] and their innate secretion of enzymes that are effective at breaking down toxic fibrils [93]. Furthermore, EVs derived from fibroblasts have been shown to induce axonal regeneration in an optic nerve injury model via wingless/integrated (Wnt) and mTOR signaling [94]. Additionally, EVs isolated from murine neuroblastoma (Neuro-2a) cells were able to reduce synaptic dysfunction and ameliorate $A \beta$ pathology in a microglial dependent manner following intracerebral administration into APP heterozygotic transgenic mice expressing the Swedish and Indiana mutations [90]. The group demonstrated that EVs are incorporated into murine microglia in a glycosphingolipid (GSL)-glycan independent manner [90]. The field of EV research in the central nervous system is still in its infancy, and yet there are already promising therapeutic applications being brought forward.

\section{Conclusion}

The research field has long held fast to proteopathic hypotheses of AD induction where cell to cell transfer of pathogenic proteins is postulated, and the topographical progression of neuritic plaques and neurofibrillary tangles have been extensively explored. Spreading through network connections could facilitate this propagation to distant areas within a neuronal network, possibly by a trans-synaptic mechanism [95]. The EV provides a suitable vector for spreading of pathogenic proteins within this context. More detailed studies are needed to prove that regional EVs transmit in patterns that mimic consortium to establish a registry for Alzheimer's disease (CERAD) and Braak staging schemata, however recent advancements in targeted EV labeling in vivo may provide a powerful tool for testing this hypothesis [96].

The pathogenic spreading of AD via cell-to-cell transfer remains far from being proven or universally accepted. Alternatively, the functional brain should also be understood as multiple interacting subsystems and connecting hubs that interact within a larger default network; all of which have been mapped using functional connectivity analyses. Brain imaging research has revealed that patients with $A D$ have a specific anatomic pattern of reduced metabolism based on fMRI relative to age-matched controls [97]. The pattern of reduced metabolism bears a striking resemblance to the regions comprising the posterior components of the default network [98]. Intriguingly, the regions within the default network that show higher resting metabolism in healthy adults are also those that are most vulnerable to damage from AD. These findings lend to the notion that changes in the default network may somehow lead to or modify amyloid deposition [99]. These regional changes in the default mode may also differentially modify EV cargo in affected networks. However, quantifying changes in EV cargos and metabolism in the context of the default mode would be extremely difficult if not impossible given the lack of unique region specific markers for circulating EVs and the inaccessibility of specific brain tissue EVs from living patients.

Multiple studies have already characterized the vesicle in both genetically manipulated experimental situations 
and in blood taken from $\mathrm{AD}$ patients, bolstering its translatable reliability. Unfortunately, despite this growing evidence supporting the importance of EVs in $\mathrm{AD}$, there is still a lack of standardization in methods [100]. Ultracentrifugation methods have been used to obtain highly pure EV fractions [101], but the reproducibility and efficiency of this method remains unclear. Many laboratories have instead opted to use microfiltration technologies, antibody-coated magnetic beads, microfluidic devices, or precipitation techniques using ExoQuick reagent, with the latter giving the most favorable outcomes in both quantity of EVs isolated and in quality of protein cargos [102]. Recently, the ExoQuick precipitation reagent was shown to yield comparable results to ultracentrifugation methods in independent studies of Down syndrome (DS) from independent labs [53, 103]. From blood, we consistently isolated $40 \%$ more NDEVs on average from DS blood when compared to controls based on the EV surface marker differentiation (CD) 81. Using ultracentrifugation methods, Levy and colleagues support this trend with evidence that post-mortem brain tissue isolated from individuals with DS expelled nearly $40 \%$ more EVs than non-DS controls based on levels of both Flotillin-1 and Flotillin-2 levels and acetylcholinesterase activity [103]. Thus it seems that orthogonal methods used by different laboratories can yield comparable outcomes in this context. While these data are promising, moving forward it is imperative that the field utilize a cohesive definition of the term "EV" in order to create inter-experimental reliability. A proposed characterization of EVs includes the combination of size profiling through particle analysis or electron microscopy and assessing the enrichment for EV-associated proteins such as CD 9, CD 63, CD 81 , and/or apoptosis-linked gene 2-interacting protein X (Alix) [104-106].

There are interesting lines of research going into both the induction of $\mathrm{AD}$ using pathogenic EVs and the sequestration of toxic plaques using exogenous healthy EVs. Ultimately, it is the hope that using these gold standard approaches will provide reliable and reproducible insight into the role that the NDEV plays in pathogenesis of AD. Furthermore, there is a pressing need to determine the potential role of EVs derived from cell types other than neurons in $\mathrm{AD}$ pathophysiology. By ensuring concrete definitions of the EV, research can reliably characterize the role these vesicles collectively play in the development or potential treatment of $\mathrm{AD}$. With the impending health care burden on our society, it is clear that the field needs an influx of novel approaches through which to study AD. The EV, with all of its connections to $\mathrm{AD}$ via aberrant metabolic pathways, provides a unique and promising research venture.

\section{Additional file}

Additional file 1: Table S1. Proteins related to neuronally derived EVs of Alzheimer's disease patients (DOCX $95 \mathrm{~kb}$ )

\begin{abstract}
Abbreviations
AD: Alzheimer's disease; Akt: Protein kinase B; Alix: Apoptosis-linked gene 2interacting protein X; AMPAR: a-amino-3-hydroxy-5-methyl-4isoxazolepropionic acid receptor; APP: Amyloid precursor protein; A $\beta$ : Betaamyloid; BACE 1: Beta secretase enzyme 1; CD: Cluster of differentiation; CERAD: Consortium to establish a registry for Alzheimer's disease; DS: Down syndrome; ESCRT: Endosomal sorting complexes required for transport; EVs: Extracellular vesicles; GAP43: Growth-associated protein 43; HSP: Heat shock protein; IRS1: Insulin receptor substrate 1; LRP6: LDL receptor related protein; MCl: Mild cognitively impaired; mTOR: Mammalian target of rapamycin; MVB: Multivesicular body; NDEVs: Neuronally derived extracellular vesicles; Neuro-2a: Murine neuroblastoma; nSMase2: Neutral sphingomyelinase-2; PrP: Prion protein receptor; p-S396-tau: Tau phosphorylation at serine 396; p-T181-tau: Tau phosphorylation at threonine 181; REST: RE1-silencing transcription factor; sAPP: Soluble APP; Wnt: Wingless/integrated
\end{abstract}

\section{Acknowledgements}

The authors wish to acknowledge Janet Boggs for editorial assistance.

\section{Funding}

This work was supported by the National Institute of Health (NINDS 1R01NS099595-01A1) and the Alzheimer's Association (AARGD-16-440893).

Availability of data and materials

All of the supporting data reported are included in this review.

\section{Authors' contributions}

LSW constructed the idea, performed the literature search, and wrote the manuscript. EDH performed the literature search and wrote the manuscript TDS performed the literature search and edited the manuscript, CS-R constructed the idea and wrote the manuscript. All authors approved the final manuscript.

Ethics approval and consent to participate Not applicable.

\section{Consent for publication}

Not applicable.

\section{Competing interests}

The authors declare that they have no competing interests.

\section{Publisher's Note}

Springer Nature remains neutral with regard to jurisdictional claims in published maps and institutional affiliations.

\section{Author details}

${ }^{1}$ Department of Neurology, Medical University of South Carolina, 96 Jonathan Lucas Street, 301 Clinical Sciences Building, MSC 606, Charleston, SC 29425, USA. ${ }^{2}$ Molecular and Cellular Biology and Pathobiology Program, Medical University of South Carolina, Charleston, Charleston, SC 29425, USA ${ }^{3}$ Department of Pathology and Laboratory Medicine, Medical University of South Carolina, Charleston, SC 29425, USA. ${ }^{4}$ Honors College, College of Charleston, Charleston, SC 29424, USA. 
Received: 27 December 2018 Accepted: 17 April 2019

Published online: 10 June 2019

\section{References}

1. Friedland RP, Koss E, Haxby JV, Grady CL, Luxenberg J, Schapiro MB, Kaye J. $\mathrm{NIH}$ conference. Alzheimer disease: clinical and biological heterogeneity. Ann Intern Med. 1988;109:298-311.

2. Mayeux R, Stern Y, Spanton S. Heterogeneity in dementia of the Alzheimer type: evidence of subgroups. Neurology. 1985;35:453-61.

3. Ritchie K, Touchon J. Heterogeneity in senile dementia of the Alzheimer type: individual differences, progressive deterioration or clinical sub-types? J Clin Epidemiol. 1992;45:1391-8.

4. Glick D, Barth S, Macleod KF. Autophagy: cellular and molecular mechanisms. J Pathol. 2010;221:3-12.

5. Pryor PR, Luzio JP. Delivery of endocytosed membrane proteins to the lysosome. Biochim Biophys Acta. 1793;2009:615-24.

6. Cecconi F, Levine B. The role of autophagy in mammalian development: cell makeover rather than cell death. Dev Cell. 2008:15:344-57.

7. Lemasters JJ. Variants of mitochondrial autophagy: types 1 and 2 mitophagy and micromitophagy (type 3). Redox Biol. 2014;2:749-54.

8. Abdulrahman BA, Abdelaziz DH, Schatzl HM. Autophagy regulates exosomal release of prions in neuronal cells. J Biol Chem. 2018:293:8956-68.

9. Pan BT, Teng K, Wu C, Adam M, Johnstone RM. Electron microscopic evidence for externalization of the transferrin receptor in vesicular form in sheep reticulocytes. J Cell Biol. 1985;101:942-8.

10. Paolicelli RC, Bergamini G, Rajendran L. Cell-to-cell communication by extracellular vesicles: focus on microglia. Neuroscience. 2018;405:148-57.

11. Soria FN, Pampliega O, Bourdenx M, Meissner WG, Bezard E, Dehay B. Exosomes, an unmasked culprit in neurodegenerative diseases. Front Neurosci. 2017:11:26.

12. Malm T, Loppi S, Kanninen KM. Exosomes in Alzheimer's disease. Neurochem Int. 2016;97:193-9.

13. Xiao $T$, Zhang $W$, Jiao B, Pan CZ, Liu X, Shen L. The role of exosomes in the pathogenesis of Alzheimer' disease. Transl Neurodegener. 2017;6:3.

14. Urbanelli L, Magini A, Buratta S, Brozzi A, Sagini K, Polchi A, Tancini B, Emiliani C. Signaling pathways in exosomes biogenesis, secretion and fate. Genes (Basel). 2013:4:152-70.

15. Villarroya-Beltri C, Baixauli F, Mittelbrunn M, Fernandez-Delgado I, Torralba D, Moreno-Gonzalo O, Baldanta S, Enrich C, Guerra S, Sanchez-Madrid F. ISGylation controls exosome secretion by promoting lysosomal degradation of MVB proteins. Nat Commun. 2016;7:13588.

16. Mayor S, Parton RG, Donaldson JG. Clathrin-independent pathways of endocytosis. Cold Spring Harb Perspect Biol. 2014;6(6).

17. Schmidt O, Teis D. The ESCRT machinery. Curr Biol. 2012;22:R116-20.

18. Eden ER, Burgoyne T, Edgar JR, Sorkin A, Futter CE. The relationship between ER-multivesicular body membrane contacts and the ESCRT machinery. Biochem Soc Trans. 2012;40:464-8.

19. Geiger R, Luisoni S, Johnsson K, Greber UF, Helenius A. Investigating endocytic pathways to the endoplasmic reticulum and to the cytosol using SNAP-trap. Traffic. 2013:14:36-46.

20. Fader CM, Colombo MI. Autophagy and multivesicular bodies: two closely related partners. Cell Death Differ. 2009;16:70-8.

21. Saxton RA, Sabatini DM. mTOR signaling in growth, metabolism, and disease. Cell. 2017:168:960-76.

22. Yoon MS. The role of mammalian target of rapamycin (mTOR) in insulin signaling. Nutrients. 2017;9(11). https://doi.org/10.3390/nu9111176.

23. Shafei MA, Harris M, Conway ME. Divergent metabolic regulation of autophagy and mTORC1-early events in Alzheimer's disease? Front Aging Neurosci. 2017;9:173.

24. Ost A, Svensson K, Ruishalme I, Brannmark C, Franck N, Krook H, Sandstrom $P$, Kjolhede $P$, Stralfors $P$. Attenuated mTOR signaling and enhanced autophagy in adipocytes from obese patients with type 2 diabetes. Mol Med. 2010;16:235-46.

25. Jung $\mathrm{CH}$, Ro $\mathrm{SH}, \mathrm{CaO} J$, Otto NM, Kim DH. mTOR regulation of autophagy. FEBS Lett. 2010:584:1287-95.

26. Majumder S, Richardson A, Strong R, Oddo S. Inducing autophagy by rapamycin before, but not after, the formation of plaques and tangles ameliorates cognitive deficits. PLoS One. 2011;6:e25416.

27. Spilman P, Podlutskaya N, Hart MJ, Debnath J, Gorostiza O, Bredesen D, Richardson A, Strong R, Galvan V. Inhibition of mTOR by rapamycin abolishes cognitive deficits and reduces amyloid-beta levels in a mouse model of Alzheimer's disease. PLoS One. 2010:5:e9979.

28. Wang IF, Guo BS, Liu YC, Wu CC, Yang CH, Tsai KJ, Shen CK. Autophagy activators rescue and alleviate pathogenesis of a mouse model with proteinopathies of the TAR DNA-binding protein 43. Proc Natl Acad Sci U S A. 2012;109:15024-9.

29. Halloran J, Hussong SA, Burbank R, Podlutskaya N, Fischer KE, Sloane LB, Austad SN, Strong R, Richardson A, Hart MJ, Galvan V. Chronic inhibition of mammalian target of rapamycin by rapamycin modulates cognitive and non-cognitive components of behavior throughout lifespan in mice. Neuroscience. 2012;223:102-13.

30. Majumder S, Caccamo A, Medina DX, Benavides AD, Javors MA, Kraig E, Strong $\mathrm{R}$, Richardson A, Oddo S. Lifelong rapamycin administration ameliorates age-dependent cognitive deficits by reducing IL-1beta and enhancing NMDA signaling. Aging Cell. 2012;11:326-35.

31. Kim B, Figueroa-Romero C, Pacut C, Backus C, Feldman EL. Insulin resistance prevents AMPK-induced tau Dephosphorylation through Akt-mediated increase in AMPKSer-485 phosphorylation. J Biol Chem. 2015;290:19146-57.

32. Tang Z, loja E, Bereczki E, Hultenby K, Li C, Guan Z, Winblad B, Pei JJ. mTor mediates tau localization and secretion: implication for Alzheimer's disease. Biochim Biophys Acta. 1853:2015:1646-57.

33. Pallo SP, DiMaio J, Cook A, Nilsson B, Johnson GW. Mechanisms of tau and Abeta-induced excitotoxicity. Brain Res. 1634;2016:119-31.

34. Momen-Heravi F, Saha B, Kodys K, Catalano D, Satishchandran A, Szabo G. Increased number of circulating exosomes and their microRNA cargos are potential novel biomarkers in alcoholic hepatitis. J Transl Med. 2015;13:261.

35. King HW, Michael MZ, Gleadle JM. Hypoxic enhancement of exosome release by breast cancer cells. BMC Cancer. 2012;12:421.

36. Xiao X, Yu S, Li S, Wu J, Ma R, Cao H, Zhu Y, Feng J. Exosomes: decreased sensitivity of lung cancer A549 cells to cisplatin. PLoS One. 2014;9:e89534.

37. Lehmann BD, Paine MS, Brooks AM, McCubrey JA, Renegar RH, Wang R, Terrian DM. Senescence-associated exosome release from human prostate cancer cells. Cancer Res. 2008;68:7864-71.

38. Atienzar-Aroca S, Flores-Bellver M, Serrano-Heras G, Martinez-Gil N, Barcia JM, Aparicio S, Perez-Cremades D, Garcia-Verdugo JM, Diaz-Llopis M, Romero FJ, Sancho-Pelluz J. Oxidative stress in retinal pigment epithelium cells increases exosome secretion and promotes angiogenesis in endothelial cells. J Cell Mol Med. 2016:20:1457-66.

39. Faure J, Lachenal G, Court M, Hirrlinger J, Chatellard-Causse C, Blot B, Grange J, Schoehn G, Goldberg Y, Boyer V, et al. Exosomes are released by cultured cortical neurones. Mol Cell Neurosci. 2006;31:642-8.

40. Savina A, Furlan M, Vidal M, Colombo MI. Exosome release is regulated by a calcium-dependent mechanism in K562 cells. J Biol Chem. 2003:278:20083-90.

41. Winston CN, Goetzl EJ, Akers JC, Carter BS, Rockenstein EM, Galasko D, Masliah E, Rissman RA. Prediction of conversion from mild cognitive impairment to dementia with neuronally derived blood exosome protein profile. Alzheimers Dement. 2016:3:63-72

42. Sardar Sinha M, Ansell-Schultz A, Civitelli L, Hildesjo C, Larsson M, Lannfelt L, Ingelsson M, Hallbeck M. Alzheimer's disease pathology propagation by exosomes containing toxic amyloid-beta oligomers. Acta Neuropathol. 2018 136:41-56.

43. Karran E, Mercken M, De Strooper B. The amyloid cascade hypothesis for Alzheimer's disease: an appraisal for the development of therapeutics. Nat Rev Drug Discov. 2011;10:698-712.

44. Kandalepas PC, Vassar R. The normal and pathologic roles of the Alzheimer's beta-secretase, BACE1. Curr Alzheimer Res. 2014;11:441-9.

45. Miranda AM, Lasiecka ZM, Xu Y, Neufeld J, Shahriar S, Simoes S, Chan RB, Oliveira TG, Small SA, Di Paolo G. Neuronal lysosomal dysfunction releases exosomes harboring APP C-terminal fragments and unique lipid signatures. Nat Commun. 2018:9:291.

46. Devi L, Anandatheerthavarada HK. Mitochondrial trafficking of APP and alpha synuclein: relevance to mitochondrial dysfunction in Alzheimer's and Parkinson's diseases. Biochim Biophys Acta. 1802;2010:11-9.

47. Pavlov PF, Hansson Petersen C, Glaser E, Ankarcrona M. Mitochondrial accumulation of APP and Abeta: significance for Alzheimer disease pathogenesis. J Cell Mol Med. 2009:13:4137-45.

48. Eitan E, Hutchison ER, Marosi K, Comotto J, Mustapic M, Nigam SM, Suire C, Maharana C, Jicha GA, Liu D, et al. Extracellular vesicle-associated Abeta mediates trans-neuronal bioenergetic and ca (2+)-handling deficits in Alzheimer's disease models. NPJ Aging Mech Dis. 2016:2. Article number: 16019. 
49. Laulagnier K, Javalet C, Hemming FJ, Chivet M, Lachenal G, Blot B, Chatellard C, Sadoul R. Amyloid precursor protein products concentrate in a subset of exosomes specifically endocytosed by neurons. Cell Mol Life Sci. 2018;75:757-73.

50. Eitan E, Suire C, Zhang S, Mattson MP. Impact of lysosome status on extracellular vesicle content and release. Ageing Res Rev. 2016:32:65-74.

51. Abner EL, Jicha GA, Shaw LM, Trojanowski JQ, Goetzl EJ. Plasma neuronal exosomal levels of Alzheimer's disease biomarkers in normal aging. Ann Clin Transl Neurol. 2016:3:399-403.

52. Fiandaca MS, Kapogiannis D, Mapstone M, Boxer A, Eitan E, Schwartz JB, Abner EL, Petersen RC, Federoff HJ, Miller BL, Goetzl EJ. Identification of preclinical Alzheimer's disease by a profile of pathogenic proteins in neurally derived blood exosomes: a case-control study. Alzheimers Dement. 2015;11:600-7 e601.

53. Hamlett ED, Goetzl EJ, Ledreux A, Vasilevko V, Boger HA, LaRosa A, Clark D, Carroll SL, Carmona-Iragui M, Fortea J, et al. Neuronal exosomes reveal Alzheimer's disease biomarkers in Down syndrome. Alzheimers Dement. 2017;13:541-9.

54. Hamlett ED, Ledreux A, Potter H, Chial HJ, Patterson D, Espinosa JM, Bettcher BM, Granholm AC. Exosomal biomarkers in Down syndrome and Alzheimer's disease. Free Radic Biol Med. 2018;114:110-21.

55. Mullins RJ, Mustapic M, Goetzl EJ, Kapogiannis D. Exosomal biomarkers of brain insulin resistance associated with regional atrophy in Alzheimer's disease. Hum Brain Mapp. 2017;38:1933-40.

56. Cohen M, Appleby B, Safar JG. Distinct prion-like strains of amyloid beta implicated in phenotypic diversity of Alzheimer's disease. Prion. 2016;10:9-17.

57. Heisler FF, Pechmann Y, Wieser I, Altmeppen HC, Veenendaal L, Muhia M, Schweizer M, Glatzel M, Krasemann S, Kneussel M. Muskelin coordinates $\operatorname{PrP}(C)$ lysosome versus exosome targeting and impacts prion disease progression. Neuron. 2018:99:1155-69 e1159.

58. Takeda S. Progression of Alzheimer's disease, tau propagation, and its modifiable risk factors. Neurosci Res. 2018;141:36-42.

59. Kapitein LC, Hoogenraad CC. Building the neuronal microtubule cytoskeleton. Neuron. 2015;87:492-506.

60. Johnson GV, Stoothoff WH. Tau phosphorylation in neuronal cell function and dysfunction. J Cell Sci. 2004;117:5721-9.

61. Martin L, Latypova X, Terro F. Post-translational modifications of tau protein: implications for Alzheimer's disease. Neurochem Int. 2011;58: 458-71.

62. Perl DP. Neuropathology of Alzheimer's disease. Mt Sinai J Med. 2010;77:32-42

63. Chesser AS, Pritchard SM, Johnson GV. Tau clearance mechanisms and their possible role in the pathogenesis of Alzheimer disease. Front Neurol. 2013;4:122.

64. de la Monte SM. Insulin resistance and Alzheimer's disease. BMB Rep. 2009;42:475-81.

65. de la Monte SM, Tong M. Brain metabolic dysfunction at the core of Alzheimer's disease. Biochem Pharmacol. 2014;88:548-59.

66. Craft S, Baker LD, Montine TJ, Minoshima S, Watson GS, Claxton A, Arbuckle M, Callaghan M, Tsai E, Plymate SR, et al. Intranasal insulin therapy for Alzheimer disease and amnestic mild cognitive impairment: a pilot clinical trial. Arch Neurol. 2012;69:29-38.

67. Draznin B. Molecular mechanisms of insulin resistance: serine phosphorylation of insulin receptor substrate-1 and increased expression of p85alpha: the two sides of a coin. Diabetes. 2006;55:2392-7.

68. Aguirre V, Werner ED, Giraud J, Lee YH, Shoelson SE, White MF. Phosphorylation of Ser307 in insulin receptor substrate-1 blocks interactions with the insulin receptor and inhibits insulin action. J Biol Chem. 2002;277:1531-7.

69. Sims-Robinson C, Bakeman A, Bruno E, Jackson S, Glasser R, Murphy GG, Feldman EL. Dietary reversal ameliorates short- and long-term memory deficits induced by high-fat diet early in life. PLoS One. 2016; $11: e 0163883$.

70. Kapogiannis D, Boxer A, Schwartz JB, Abner EL, Biragyn A, Masharani U, Frassetto L, Petersen RC, Miller BL, Goetzl EJ. Dysfunctionally phosphorylated type 1 insulin receptor substrate in neural-derived blood exosomes of preclinical Alzheimer's disease. FASEB J. 2015:29:589-96.

71. Goetzl EJ, Kapogiannis D, Schwartz JB, Lobach IV, Goetzl L, Abner EL, Jicha GA, Karydas AM, Boxer A, Miller BL. Decreased synaptic proteins in neuronal exosomes of frontotemporal dementia and Alzheimer's disease. FASEB J. 2016:30:4141-8.

72. Goetzl EJ, Boxer A, Schwartz JB, Abner EL, Petersen RC, Miller BL, Carlson OD, Mustapic M, Kapogiannis D. Low neural exosomal levels of cellular survival factors in Alzheimer's disease. Ann Clin Transl Neurol. 2015;2:769-73.
73. Goetzl EJ, Abner EL, Jicha GA, Kapogiannis D, Schwartz JB. Declining levels of functionally specialized synaptic proteins in plasma neuronal exosomes with progression of Alzheimer's disease. FASEB J. 2018;32:888-93.

74. Lee M, Ban JJ, Yang S, Im W, Kim M. The exosome of adipose-derived stem cells reduces beta-amyloid pathology and apoptosis of neuronal cells derived from the transgenic mouse model of Alzheimer's disease. Brain Res. 1691;2018:87-93.

75. Polanco JC, Li C, Durisic N, Sullivan R, Gotz J. Exosomes taken up by neurons hijack the endosomal pathway to spread to interconnected neurons. Acta Neuropathol Commun. 2018;6:10.

76. Winston CN, Aulston B, Rockenstein EM, Adame A, Prikhodko O, Dave KN, Mishra P, Rissman RA, Yuan SH: Neuronal exosome-derived human tau is toxic to recipient mouse neurons in vivo. J Alzheimers Dis 2019, 67:541-553.

77. Ngolab J, Trinh I, Rockenstein E, Mante M, Florio J, Trejo M, Masliah D, Adame A, Masliah E, Rissman RA. Brain-derived exosomes from dementia with Lewy bodies propagate alpha-synuclein pathology. Acta Neuropathol Commun. 2017;5:46

78. Dinkins MB, Enasko J, Hernandez C, Wang G, Kong J, Helwa I, Liu Y, Terry AV $J r$, Bieberich E. Neutral Sphingomyelinase-2 deficiency ameliorates Alzheimer's disease pathology and improves cognition in the 5XFAD mouse. J Neurosci. 2016;36:8653-67.

79. Hartmann A, Muth C, Dabrowski O, Krasemann S, Glatzel M. Exosomes and the prion protein: more than one truth. Front Neurosci. 2017;11:194.

80. Kellett KA, Hooper NM. Prion protein and Alzheimer disease. Prion. 2009;3:190-4.

81. Prusiner SB. Novel proteinaceous infectious particles cause scrapie. Science. 1982;216:136-44.

82. Gimbel DA, Nygaard HB, Coffey EE, Gunther EC, Lauren J, Gimbel ZA, Strittmatter SM. Memory impairment in transgenic Alzheimer mice requires cellular prion protein. J Neurosci. 2010;30:6367-74.

83. Vergara C, Ordonez-Gutierrez L, Wandosell F, Ferrer I, del Rio JA, Gavin R. Role of $\operatorname{PrP}(\mathrm{C})$ expression in tau protein levels and phosphorylation in Alzheimer's disease evolution. Mol Neurobiol. 2015;51:1206-20.

84. Jarosz-Griffiths HH, Noble E, Rushworth JV, Hooper NM. Amyloid-beta receptors: the good, the bad, and the prion protein. J Biol Chem. 2016;291: 3174-83.

85. Fevrier B, Vilette D, Archer F, Loew D, Faigle W, Vidal M, Laude $H$, Raposo G. Cells release prions in association with exosomes. Proc Nat Acad Sci U S A. 2004;101:9683-8.

86. Lee BR, Kim JH, Choi ES, Cho JH, Kim E. Effect of young exosomes injected in aged mice. Int J Nanomedicine. 2018;13:5335-45.

87. Yuyama K, Igarashi Y. Exosomes as carriers of Alzheimer's amyloid-ss. Front Neurosci. 2017;11:229

88. Yuyama K, Sun H, Mitsutake S, Igarashi Y. Sphingolipid-modulated exosome secretion promotes clearance of amyloid-beta by microglia. J Biol Chem. 2012;287:10977-89.

89. Quek $\mathrm{C}$, Hill AF. The role of extracellular vesicles in neurodegenerative diseases. Biochem Biophys Res Commun. 2017;483:1178-86.

90. Yuyama K, Sun H, Sakai S, Mitsutake S, Okada M, Tahara H, Furukawa J, Fujitani N, Shinohara Y, Igarashi Y. Decreased amyloid-beta pathologies by intracerebral loading of glycosphingolipid-enriched exosomes in Alzheimer model mice. J Biol Chem. 2014;289:24488-98.

91. Xin H, Li Y, Cui Y, Yang JJ, Zhang ZG, Chopp M. Systemic administration of exosomes released from mesenchymal stromal cells promote functional recovery and neurovascular plasticity after stroke in rats. J Cereb Blood Flow Metab. 2013:33:1711-5.

92. Chen CC, Liu L, Ma F, Wong CW, Guo XE, Chacko JV, Farhoodi HP, Zhang SX, Zimak J, Segaliny A, et al. Elucidation of exosome migration across the blood-brain barrier model in vitro. Cell Mol Bioeng. 2016;9:509-29.

93. Katsuda T, Oki K, Ochiya T. Potential application of extracellular vesicles of human adipose tissue-derived mesenchymal stem cells in Alzheimer's disease therapeutics. Methods Mol Biol. 2015;1212:171-81.

94. Tassew NG, Charish J, Shabanzadeh AP, Luga V, Harada H, Farhani N, D'Onofrio P, Choi B, Ellabban A, Nickerson PEB, et al. Exosomes mediate mobilization of autocrine Wnt10b to promote axonal regeneration in the injured CNS. Cell Rep. 2017;20:99-111.

95. Stancu IC, Vasconcelos B, Ris L, Wang P, Villers A, Peeraer E, Buist A, Terwel $D$, Baatsen $P$, Oyelami T, et al. Templated misfolding of tau by prion-like seeding along neuronal connections impairs neuronal network function and associated behavioral outcomes in tau transgenic mice. Acta Neuropathol. 2015;129:875-94. 
96. Chuo ST, Chien JC, Lai CP. Imaging extracellular vesicles: current and emerging methods. J Biomed Sci. 2018;25:91.

97. Minoshima S, Giordani B, Berent S, Frey KA, Foster NL, Kuhl DE. Metabolic reduction in the posterior cingulate cortex in very early Alzheimer's disease. Ann Neurol. 1997:42:85-94.

98. Buckner RL, Andrews-Hanna JR, Schacter DL. The brain's default network: anatomy, function, and relevance to disease. Ann N Y Acad Sci. 2008;1124:1-38.

99. Buckner RL, Snyder AZ, Shannon BJ, LaRossa G, Sachs R, Fotenos AF, Sheline Yl, Klunk WE, Mathis CA, Morris JC, Mintun MA. Molecular, structural, and functional characterization of Alzheimer's disease: evidence for a relationship between default activity, amyloid, and memory. J Neurosci. 2005;25:7709-17.

100. Caradec J, Kharmate G, Hosseini-Beheshti E, Adomat H, Gleave M, Guns E. Reproducibility and efficiency of serum-derived exosome extraction methods. Clin Biochem. 2014;47:1286-92.

101. Webber J, Clayton A. How pure are your vesicles? J Extracell Vesicles. 2013;2. https://doi.org/10.3402/jev.v2i0.19861.

102. Taylor DD, Zacharias W, Gercel-Taylor C. Exosome isolation for proteomic analyses and RNA profiling. Methods Mol Biol. 2011;728:235-46.

103. Gauthier SA, Perez-Gonzalez R, Sharma A, Huang FK, Alldred MJ, Pawlik M, Kaur G, Ginsberg SD, Neubert TA, Levy E. Enhanced exosome secretion in Down syndrome brain - a protective mechanism to alleviate neuronal endosomal abnormalities. Acta Neuropathol Commun. 2017;5:65.

104. Colombo M, Raposo G, Thery C. Biogenesis, secretion, and intercellular interactions of exosomes and other extracellular vesicles. Annu Rev Cell Dev Biol. 2014;30:255-89.

105. Kowal J, Arras G, Colombo M, Jouve M, Morath JP, Primdal-Bengtson B, Dingli F, Loew D, Tkach M, Thery C. Proteomic comparison defines novel markers to characterize heterogeneous populations of extracellular vesicle subtypes. Proc Natl Acad Sci U S A. 2016;113:E968-77.

106. Lotvall J, Hill AF, Hochberg F, Buzas El, Di Vizio D, Gardiner C, Gho YS, Kurochkin IV, Mathivanan S, Quesenberry P, et al. Minimal experimental requirements for definition of extracellular vesicles and their functions: a position statement from the International Society for Extracellular Vesicles. J Extracell Vesicles. 2014;3:26913.

Ready to submit your research? Choose BMC and benefit from:

- fast, convenient online submission

- thorough peer review by experienced researchers in your field

- rapid publication on acceptance

- support for research data, including large and complex data types

- gold Open Access which fosters wider collaboration and increased citations

- maximum visibility for your research: over $100 \mathrm{M}$ website views per year

At $\mathrm{BMC}$, research is always in progress.

Learn more biomedcentral.com/submissions 